\title{
Method of System Optimization of Mobile Formations Activity
}

\author{
Pavel Oleinik* \\ National Research Moscow State University of Civil Engineering, Moscow, Russia
}

\begin{abstract}
The distinctive features of mobile construction units operating at a considerable distance from the places of permanent residence of workers and the location of construction organizations have been considered. For their effective activity, a high level of synchronization of the stages of preparation of a construction organization and their formations, preparation for the construction of the facilities, delivery of labor and material and technical resources, production of pioneer, preparatory and construction and installation works is required. A method has been proposed that includes the definition of a system of indicators for regulating the parameters of the above stages for compliance with the design solutions. The system of indicators makes it possible to assess not only the level of mobility of construction units and the means of their technical equipment, but also to express the actual intensity of work through the concentration of the resources. As a result, it becomes possible to compare the actual and design intensities of work with the subsequent development of appropriate measures in advance, taking into account the conditions of hard-to-reach and sparsely populated areas of pioneering development of the territories. At the same time, such measures, as studies have shown, include the use, as a rule, of only existing resources on the spot without attracting additional ones from outside.
\end{abstract}

\section{Introduction}

The fundamental difference between the activities of mobile construction units from the activities of traditional construction structures is, first of all, in the performance of construction and installation work at a considerable distance from the places of permanent deployment of the construction organization, the area of permanent residence of workers and the location of the logistics bases [1]. As a result, mobile formations are forced to independently and autonomously carry out the entire range of life support measures throughout the entire period of work and solve all emerging tasks for the implementation of the pioneer, preparatory and main periods of construction of buildings and structures. In particular, only the implementation of life support measures includes a whole complex and balanced system of housing and communal services, social welfare and medical services for workers. At the same time, in order to create normal conditions for those working on a rotational (expeditionary) method, it is necessary to reliably provide them with heat, water,

\footnotetext{
${ }^{*}$ Corresponding author: cniomtp@mail.ru
} 
food, energy, transport and communications. In most cases, their activities take place in difficult, and sometimes in severe natural and climatic conditions. And therefore, the main task of the activities of the mobile formations is to achieve the uninterrupted operation of their watches and expeditions, since the arrangement and cost of labor for workers is very expensive. At the same time, it is very difficult to correctly predict the development of construction production in new severe conditions due to disruptions and even minor violations of the calculated adaptation of workers, the breakdown of construction machinery and equipment as a result of extreme climatic effects, and complex transport links with rear bases. In this regard, the issues of achieving a high level of synchronization of all stages of preparation and construction of facilities in order to minimize their duration and reduce the cost of human labor are especially acute [2, 3]. Foreign and domestic practice of construction development of regions with difficult natural and climatic conditions in the Far North, Siberia and mountainous regions repeatedly faces the need to solve the above problem, which, due to the active development of hard-to-reach territories, is becoming an extremely important and little-studied direction.

\section{Materials and methods}

The activities of any mobile construction organization include the constant implementation of such stages as the preparation of a construction organization and its formations, preparation for the construction of the facilities, delivery of labor resources and a wide range of construction materials to the facilities, organization and production of various construction and installation works. All these stages are interconnected by a common goal to timely put high-quality facilities into operation [4-7]. At the same time, each stage has its own specific features that directly or indirectly affect the implementation of the activities of the next stage. So at the stage of preparing a construction organization for the transition to the mobile status, for example, it is necessary to implement a number of measures, including the development and approval of the "Regulations on the rotational (expeditionary) method of organizing the work", to enact an order on the appropriate transfer of workers to the rotational work, notify each employee in writing and conclude additional agreements to their labor contracts. In addition to these organizational measures, at the stage of preparation of the construction organization, it is necessary to solve a whole range of other organizational, technical, technological and economic issues [8,9].

The statement of the problem consists in identifying such characteristics at each stage that would allow, on the one hand, to assess the level of implementation of the planned activities, and on the other hand, indicate the need for their adjustment $[10,11]$.

The stage of preparation of the construction organization and its formations is extremely responsible, since it is here that the degree of compliance with the performance of all functions of the mobile system is determined. Among the numerous activities of this stage, two decisive ones can be distinguished - the full readiness of the workers to perform the work on a rotational (expeditionary) basis and sufficient equipment of the formations with mobile elements for life support and work.

The main form of organizing the work of the mobile formations is a brigade form with a breakdown of the brigades, if necessary, into specialized units. Depending on the nature of the work, the brigades can be both, complex and specialized. In the documents for the transfer of the organizational structures to mobile work methods, all aspects of the activity shall be indicated in detail. In particular, the "Regulations on the rotational method of organizing work" discloses a complete mechanism on working conditions - the organization of work, including the delivery of workers to and from the shift, housing and communal services and social services for workers, the mode of work and rest, the procedure for remuneration and compensation. At the same time, the order on the introduction of the 
rotational method of work in the construction organization specifies the corresponding divisions that are moving to the shift, the duration of the rotation and shifts, the date of the start of the rotational method. As a rule, the readiness of the workers to perform the work on a rotational (expeditionary) method can be assessed through the number of brigades transferred to this method, namely

$$
K_{M}^{(1)}=\frac{b}{B}
$$

where $K_{M}^{(1)}$ is the degree of mobility of the construction organization (formation) in terms of the workforce;

$b$ - number of brigades transferred to mobile forms of work organization;

$B$ - total number of brigades of the construction organization (formation).

The equipment of mobile formations includes a large and varied range of construction equipment, vehicles, mobile (inventory) buildings, etc. (Table 1) that can

Table 1. Distribution of mobile elements by construction periods (fragment)

\begin{tabular}{|c|c|c|c|c|}
\hline \multirow{2}{*}{$\begin{array}{l}\text { Ser. } \\
\text { No. }\end{array}$} & \multirow[b]{2}{*}{ Group of mobile elements } & \multicolumn{3}{|c|}{ Construction period } \\
\hline & & pioneer & preparatory & main \\
\hline 1 & $\begin{array}{l}\text { Construction equipment (excavators, bulldozers, } \\
\text { scrapers, graders, tower cranes, truck cranes, crawler } \\
\text { cranes, pneumatic-wheel cranes, concrete pumps, } \\
\text { etc.) }\end{array}$ & $\mathrm{H}$ & $\mathrm{H}, \mathrm{P}$ & $\mathrm{H}, \mathrm{P}$ \\
\hline 2 & $\begin{array}{l}\text { Motor transport (dump trucks, road trains, special } \\
\text { vehicles, etc.) }\end{array}$ & $\mathrm{H}, \mathrm{P}$ & $\mathrm{H}, \mathrm{P}$ & $\mathrm{H}, \mathrm{P}$ \\
\hline 3 & $\begin{array}{l}\text { Means of ensuring the technical operation of the } \\
\text { machines (mobile repair shops, fuel tankers, trailers, } \\
\text { heavy-locomotives, tractors, etc.) }\end{array}$ & $\mathrm{H}$ & $\mathrm{H}, \mathrm{P}$ & $\mathrm{H}, \mathrm{P}$ \\
\hline 4 & $\begin{array}{l}\text { Mobile (inventory) buildings (residential, public, } \\
\text { industrial, warehouse, auxiliary) }\end{array}$ & $\mathrm{H}, \mathrm{P}$ & $\mathrm{H}, \mathrm{P}$ & $\mathrm{H}$ \\
\hline 5 & $\begin{array}{l}\text { Engineering equipment and installations (power } \\
\text { plants, boiler houses, transformer substations, } \\
\text { pumping stations, water treatment plants, } \\
\text { switchboards, engineering and road networks, etc.) }\end{array}$ & $\mathrm{H}, \mathrm{P}$ & $\mathrm{H}$ & $\mathrm{H}$ \\
\hline 6 & $\begin{array}{l}\text { Process equipment (kits for assembling prefabricated } \\
\text { structures, kits for assembling metal structures, kits } \\
\text { for welding and cutting, kits for fastening and } \\
\text { aligning structures, etc.) }\end{array}$ & $\mathrm{H}$ & $\mathrm{H}$ & $\mathrm{H}, \mathrm{P}$ \\
\hline 7 & $\begin{array}{l}\text { Inventory formwork sets (large-panel, small-panel, } \\
\text { fixed, sliding, heating, etc.) }\end{array}$ & $\mathrm{H}$ & $\mathrm{H}$ & $\mathrm{H}$ \\
\hline 8 & $\begin{array}{l}\text { Small-scale mechanization equipment (standard kits } \\
\text { for assembling prefabricated panel buildings, } \\
\text { flooring, laying pipelines, performing waterproofing, } \\
\text { etc.) }\end{array}$ & $\mathrm{H}$ & $\mathrm{H}$ & $\mathrm{H}$ \\
\hline 9 & $\begin{array}{l}\text { Hand tools (construction and assembly, control and } \\
\text { measuring, for assemblers, riggers, concrete } \\
\text { workers, fitters, electric welders, carpenters, etc.) }\end{array}$ & $\mathrm{H}$ & $\mathrm{H}$ & $\mathrm{H}$ \\
\hline
\end{tabular}

be leased or be on the balance sheet of a construction organization. The structure of the mobile equipment elements is established in construction management projects and directly depends on the type of construction and the structure of construction and installation works. As a rule, it is formed separately for the pioneering development of the territory and the periods of construction of the main facilities [12]. The sufficiency of the technical equipment of mobile formations can be defined as

$$
K_{M}^{(2)}=\frac{\sum_{i=1}^{n} \sum_{j=1}^{m} \varphi_{i j}^{M}}{\sum_{j=1}^{m} \varphi_{j}+\sum_{l=1}^{L} U_{l}}
$$


where $K_{M}^{(2)}$ is the degree of mobility of the construction organization (formation) by means of technical equipment;

$\varphi_{i j}^{M}$ - cost of mobile elements of the $j$-th group, required for the construction of the $i$-th object, $i=1,2, \ldots, \mathrm{n} ; j=1,2, \ldots, m$;

$\varphi_{j}$ - the cost of mobile elements of the $j$-th group in a construction organization;

$U_{l}$ - the cost of stationary elements of the $l$-th group in a construction organization, $l=1,2, \ldots, L$.

At the stage of preparation for the construction of an object, among traditional activities such as obtaining and thoroughly studying design and working documentation, accepting a site (territory) for construction, concluding contracts for the supply of material and technical resources, etc., a work production project is being developed, which determines the most effective

methods of performing construction and installation work, providing for a reduction in their cost and labor intensity, reduction in the time required for certain types of work, increased use of construction equipment, and improvement in the quality of construction products [13]. At the same time, the development and implementation of solutions for the work production project are based on the fundamental condition of the sufficiency of labor and material and technical resources.

With regard to the regular labor force, this condition will be written as

$$
\eta(t)=f(t)=\text { const }
$$

where $\eta(t)$ is the function expressing the need for workers in the leading process for all objects of the construction organization;

$f(t)$ - a function that expresses the availability of workers to carry out the leading process.

Then the objective function takes the following form:

$$
\left[f_{h}(t)-\eta_{h}(t)\right] \rightarrow \min
$$

where $f_{h}(t), \eta_{h}(t)$ are the functions expressing, respectively, the presence and need for workforce for the $h$-thprocess.

The values of these functions are determined from the condition that the number of workers in the planning period can be considered as constant. Then

$$
\eta_{t}=\frac{\sum_{i=1}^{n} V_{i}}{T}=R=\text { const } \quad f_{h}(t)=F_{h}=\text { const }
$$

where $F_{h}$ is the total availability of workers for the $h$-th process;

$V_{i}$ - annual volume of work on the leading process at the $i$-th object, expressed in terms of labor intensity;

$\mathrm{T}$ is the annual production resource in the planned period;

$R$ - the number of the operating links required to carry out this work at all sites.

The final functionality will be written as

under the following conditions

$$
\left[F_{h}-R_{h}(t)\right] \rightarrow \min
$$

$$
\left.\begin{array}{l}
F=R \\
t_{i} \leq \tau_{i}
\end{array}\right\}
$$

where $t_{i}, \tau_{i}$ is, respectively, the construction completion date according to the model and the target construction completion date.

If these conditions are met, all facilities will be fully provided with working personnel.

At the same time, if $F<R$, then

which indicates a simple workforce.

$$
\begin{array}{r}
F_{h}-R_{h}(t)<\Delta R \\
t_{i} \leq \tau_{i},
\end{array}
$$


If $F>R$, then

$$
\begin{aligned}
F_{h}-R_{h}(t)>\Delta R \\
t_{i} \geq \tau_{i}
\end{aligned}
$$

This means that with a given organization of construction of the facilities, there is a shortage of workers.

With regard to the means of technical equipment of mobile formations, the sufficiency condition is expressed for each of their groups, i.e.

$$
\left[\varphi_{j-} \sum_{i=1}^{n} \psi_{i j}(t)\right] \geq 0
$$

where $\psi_{i j}(t)$ is the cost of mobile elements of the $j$-th group sent for the construction of the $i$-thobject.

At the same time, the nomenclature of elements for each group of technical equipment must fully correspond to the design one, or its individual elements must have an equivalent

\begin{tabular}{|c|c|c|c|c|}
\hline $\begin{array}{l}\text { Type } \\
\text { of } \\
\text { work }\end{array}$ & Process name & $\begin{array}{c}\text { Nomenclature } \\
\text { of construction machinery }\end{array}$ & $\begin{array}{c}\text { Measuring } \\
\text { unit }\end{array}$ & $\begin{array}{c}\text { Need for } \\
\text { construction } \\
\text { machines } \\
\text { when working } \\
\text { in one shift per } \\
\text { unit., pcs. }\end{array}$ \\
\hline 1 & 2 & 3 & 4 & 5 \\
\hline \multirow[t]{5}{*}{$\begin{array}{l}\text { Excava } \\
\text { tion }\end{array}$} & $\begin{array}{l}\text { Excavation during the } \\
\text { construction of excavations and } \\
\text { embankments }\end{array}$ & $\begin{array}{l}\text { Single-bucket excavators - } \\
\text { front shovel with bucket } \\
\text { capacity, } \mathrm{m}^{3} \\
0.4 \\
0.65 \\
0.80 \\
1.0 \\
1.25\end{array}$ & $\begin{array}{c}1,000 \mathrm{~m}^{3} \\
\text { in a dense } \\
\text { body }\end{array}$ & $\begin{array}{l}0.0164 \\
0.0107 \\
0.0077 \\
0.0063 \\
0.0058\end{array}$ \\
\hline & $\begin{array}{l}\text { Development of the soil during } \\
\text { the construction of excavations } \\
\text { and embankments will be } \\
\text { carried out with loading into } \\
\text { vehicles }\end{array}$ & $\begin{array}{l}\text { Single-bucket excavators - } \\
\text { front shovel with bucket } \\
\text { capacity, } \mathrm{m}^{3} \\
0.4 \\
0.65 \\
0.80 \\
1.0 \\
1.6\end{array}$ & $\begin{array}{c}1,000 \mathrm{~m}^{3} \\
\text { in a dense } \\
\text { body }\end{array}$ & $\begin{array}{l}0.0231 \\
0.0152 \\
0.0100 \\
0.0087 \\
0.0058\end{array}$ \\
\hline & Excavation in the pits & $\begin{array}{l}\text { Single-bucket excavators - } \\
\text { reverse shovel with bucket } \\
\text { capacity, } \mathrm{m}^{3} \\
0.4 \\
0.65 \\
1.0\end{array}$ & $\begin{array}{c}1,000 \mathrm{~m}^{3} \\
\text { in a dense } \\
\text { body }\end{array}$ & $\begin{array}{l}0.0211 \\
0.0150 \\
0.0085\end{array}$ \\
\hline & $\begin{array}{l}\text { Excavation in } \\
\text { the pits with loading into } \\
\text { transport }\end{array}$ & $\begin{array}{c}\text { Single-bucket excavators } \\
\text { - reverse shovel with } \\
\text { bucket capacity, } \mathrm{m}^{3} \\
0.4 \\
0.65 \\
1.0 \\
\end{array}$ & $\begin{array}{c}1,000 \mathrm{~m}^{3} \\
\text { in a dense } \\
\text { body }\end{array}$ & $\begin{array}{l}0.0341 \\
0.0242 \\
0.0137\end{array}$ \\
\hline & Excavation in the trenches & $\begin{array}{l}\text { Single-bucket excavators - } \\
\text { reverse shovel with bucket } \\
\text { capacity, } \mathrm{m}^{3} \\
0.4 \\
0.65 \\
1.0\end{array}$ & $\begin{array}{c}1,000 \mathrm{~m}^{3} \\
\text { in a dense } \\
\text { body }\end{array}$ & $\begin{array}{l}0.0198 \\
0.0136 \\
0.0077\end{array}$ \\
\hline
\end{tabular}
replacement (Table 2).

Table 2. Nomenclature of the "Construction Equipment" group (fragment). 
Table 2. Continued

\begin{tabular}{|c|c|c|c|c|}
\hline \multirow[t]{4}{*}{$\begin{array}{l}\text { Excava } \\
\text { tion }\end{array}$} & $\begin{array}{l}\text { The same applies to loading } \\
\text { into vehicles }\end{array}$ & $\begin{array}{l}\text { Single-bucket excavators - } \\
\text { reverse shovel with bucket } \\
\text { capacity, } \mathrm{m}^{3} \\
0.4 \\
0.65 \\
1.0\end{array}$ & $-\langle\langle\rangle\rangle-$ & $\begin{array}{l}0.0288 \\
0.0203 \\
0.0115\end{array}$ \\
\hline & Cutting the vegetation layer & $\begin{array}{l}\text { Bulldozers on tractors of } \\
\text { class } 10 \mathrm{t} \text { of traction } \\
\text { Graders (medium) }\end{array}$ & $\begin{array}{l}1,0000 \mathrm{~m}^{2} \\
\text { clean } \\
\text { surface } \\
-\langle\langle\rangle-\end{array}$ & $\begin{array}{l}0.0078 \\
0.0162\end{array}$ \\
\hline & $\begin{array}{l}\text { Excavation and movement of } \\
\text { soil }\end{array}$ & $\begin{array}{l}\text { Trailed scrapers with soil } \\
\text { movement up to } 300 \mathrm{~m} \text { on } \\
\text { tractors of the class, } \mathrm{t} \text { of } \\
\text { traction } \\
\begin{array}{l}6 \\
10\end{array}\end{array}$ & $\begin{array}{l}1,000 \mathrm{~m}^{3} \text { by } \\
\text { volume in a } \\
\text { dense body }\end{array}$ & $\begin{array}{l}0.0166 \\
0.0119\end{array}$ \\
\hline & $\begin{array}{l}\text { Excavation of soil by dredgers } \\
\text { with alluvion of areas }\end{array}$ & $\begin{array}{l}\text { Dredger capacity of } 1,200- \\
1,400 \mathrm{~m}^{3} \text { by water }\end{array}$ & $\begin{array}{l}1,000 \mathrm{~m}^{3} \text { of } \\
\text { soil }\end{array}$ & 0.0159 \\
\hline \multirow[t]{4}{*}{ Pile } & $\begin{array}{l}\text { Vertical immersion of } \\
\text { reinforced concrete piles }\end{array}$ & $\begin{array}{l}\text { Installations based on } \\
\text { mechanical excavator } \\
\text { cranes with a load capacity } \\
\text { of up to } 20 \text { tons }\end{array}$ & $\begin{array}{l}1,000 \mathrm{~m}^{3} \text { of } \\
\text { reinforced } \\
\text { concrete } \\
\text { piles }\end{array}$ & 0.5023 \\
\hline & $\begin{array}{l}\text { Vertical immersion of } \\
\text { reinforced concrete piles in } \\
\text { cramped conditions }\end{array}$ & $\begin{array}{l}\text { Installations based on } \\
\text { mechanical excavator } \\
\text { cranes with a load capacity } \\
\text { of up to } 20 \text { tons }\end{array}$ & $\begin{array}{l}1,000 \mathrm{~m}^{3} \text { of } \\
\text { reinforced } \\
\text { concrete } \\
\text { piles }\end{array}$ & 0.6333 \\
\hline & $\begin{array}{l}\text { Immersion of reinforced } \\
\text { concrete piles of sheet pile row }\end{array}$ & $\begin{array}{l}\text { Installations based on } \\
\text { mechanical excavator } \\
\text { cranes with a load capacity } \\
\text { of up to } 20 \text { tons }\end{array}$ & $\begin{array}{l}1,000 \mathrm{~m}^{3} \text { of } \\
\text { reinforced } \\
\text { concrete } \\
\text { piles }\end{array}$ & 0.7317 \\
\hline & $\begin{array}{l}\text { Vertical immersion of steel } \\
\text { piles }\end{array}$ & $\begin{array}{l}\text { Installations based on } \\
\text { mechanical excavator } \\
\text { cranes with a load capacity } \\
\text { of up to } 20 \text { tons }\end{array}$ & $\begin{array}{l}1,000 \text { tons } \\
\text { of steel } \\
\text { piles }\end{array}$ & 0.1769 \\
\hline
\end{tabular}

An important stage in the application of mobile forms of organizing construction is the delivery of labor and material and technical resources to the development area. It should be noted here that the cost of delivery of these resources is up to $30 \%$ of the cost of construction and installation work, and the duration of delivery can reach up to $25-40 \%$ of the total duration of construction [3].

The delivery of shift workers from their permanent place of residence to the objects under construction and back is carried out both by the construction organization's own vehicles and by vehicles provided on the basis of contracts concluded by organizations of railway and road transport, civil aviation, and river fleet.The choice of the route for the delivery of workers and the type of vehicles shall be carried out taking into account the lowest costs in terms of cost and time of their stay on the way, the existing transport scheme in this area, indicators of transport fatigue and reduced working capacity.

During the delivery process, the workers cross both climatic zones, usually in the meridian direction, and time zones in a wide direction. As a result, the worker is simultaneously affected by the so-called "climatic shock" and stress, which causes a disorder of the physiological functions of the body. With such influences, it is difficult for the body to adapt and rehabilitate in a very short time, for example, with a rotational method of organizing work. Therefore, from this point of view, the expeditionary method is more effective, which excludes frequent transfers of workers and ensures their longer work in extreme conditions. In general, this issue requires additional thorough studies of the behavior of the workers in various regions with changing schemes of mobile organization 
of work, and only after medical and biological recommendations, the corrective factors can be introduced into the mobile construction system itself.

As a rule, the turnover of employees is carried out by brigade, but in some cases, the change can be made per team.

The basis for monitoring and evaluating the delivery of workers and material and technical resources is the turnover schedules of workers, work schedules, schedules for the delivery of materials, products, structures and equipment to the facility. In the case of using the complete block method of building an object, the schedules for the complete delivery of blocks are used.

\section{Results and discussions}

The design characteristic is determined separately for the pioneering development of the territory, the preparatory and main periods of construction of each $i$-th facility according to the groups of the same name, for example, deforestation, earthworks, assembly of prefabricated structures, installation of monolithic reinforced concrete structures, etc. in the following way:

$$
J_{\alpha}^{\mathrm{P}}=\frac{\sum_{\beta=1}^{d} q_{\alpha \beta}}{t_{\alpha}}
$$

where $J_{\alpha}^{\mathrm{P}}$ is the indicator of the design intensity of work in the group $\alpha$;

$q_{\alpha \beta}$ - estimated volume of $\beta$-th work in the group $\alpha$;

$t_{\alpha}$ - estimated total duration of work for group $\alpha$;

$$
\alpha=1,2, \ldots, s ; \beta=1,2, \ldots, \alpha
$$

The indicators of the actual intensity of work are determined in a similar way as

$$
J_{\alpha}^{\phi}=\frac{\sum_{\beta=1}^{d} P_{\alpha \beta}}{\tau_{\alpha}}
$$

where $J_{\alpha}^{\phi}$ is the indicator of the actual intensity of work in the group $\alpha$;

$P_{\alpha \beta}$ - actual volume of $\beta$-th work in the group $\alpha$;

$\tau_{\alpha}$ - actual total duration of work for group $\alpha$;

$$
\alpha=1,2, \ldots, s ; \beta=1,2, \ldots, \alpha
$$

The resulting final assessment characterizes not only the degree of concentration of resources, but also allows us to assess their performance in difficult conditions of mobile construction, i.e.

$$
K_{\mathrm{M}}^{(3)}=\frac{J_{\alpha}^{\mathrm{P}}}{J_{\alpha}^{\phi}}
$$

As a result, the following three cases can be distinguished.

1. $J_{\alpha}^{\mathrm{P}}=J_{\alpha}^{\phi}, K_{\mathrm{M}}^{(3)}=1$

The work is carried out in accordance with the decisions of the design documentation.

2. $J_{\alpha}^{\mathrm{P}}>J_{\alpha}^{\phi}, K_{\mathrm{M}}^{(3)}>1$

The production of works is developing with a lag behind the design solutions and additional measures are required to level the situation.

3. $J_{\alpha}^{\mathrm{P}}<J_{\alpha}^{\phi}, \quad K_{\mathrm{M}}^{(3)}<1$

The production of works is developing ahead of design decisions.

\section{Conclusion}

Effective autonomous activity of mobile formations at a considerable distance from the location of the construction organization and its material and technical base is achieved 
only with extremely high industrialization and synchronization of all stages of preparation and construction with the maximum reduction in the duration of the construction of facilities and the cost of human labor at construction sites.

To regulate the degree of synchronization of the stages of preparation of a construction organization and its formations, preparation for the construction of facilities, delivery of labor and material and technical resources, production of pioneering, preparatory and construction and installation works, a method has been proposed that includes a system of indicators characterizing the level of their compliance with design solutions.

As a result, a tool appears to optimize not only the degree of mobility of organizational structures in terms of workforce and means of their technical equipment, but also to establish the optimal parameters of the intensity of work through the appropriate concentration of resources.

An important area of research in the field of mobile construction is the study of adaptation and acclimatization of workers in various extreme conditions to form a set of adaptability schemes of the body to the effects of climatic aggression.

\section{References}

1. D.V.Borisov, Rotational method as a special form of organization of the labor process: dissertation, 143 (2004)

2. Rotational work in the oil industry, Analytical journal "PETROLEUM" (2001)

3. V.M.Agapkin, A.D.Khaitun, Rotational construction method, 61 (1990)

4. P.Oleinik, A.Yurgaytis, MATEC Web of Conferences, 117, 00130 (2017)

5. P.Oleinik, A.Yurgaytis, MATEC Web of Conferences, 193, 05010 (2018)

6. P.Oleinik, MATEC Web of Conferences, 164, 0030 (2020)

7. John C. Goodpasture, Quantitative methods in project management (2004)

8. Guidelines for the organization of shift work in construction, 53 (2007)

9. V.A. Zarenkov, Problems of development of construction companies in the Russian economy, 288 (1999)

10. P. Oleinik, A. Yurgaytis, IOP Conf. Series: Materials Science and Engineering, 753, 032077 (2020)

11. Garold D. Oberlender, Project management for engineering and construction, 368 (2000)

12. P.P. Oleinik, B.F. Shirshikov, Organization of construction of facilities by mobile formations, 422 (2008)

13. L.V. Kievsky, Planning and organization of construction of engineering communications, 465 (2008) 